span of $6 \frac{3}{4}$ in., which was discovered by Dr. R. A. Wallace in Borneo. The sex ratio is such that the female is about one to every thousand males. The long-tailed blue butterfly of the English list also occurs here, and there are many skippers. There is also the giant atlas moth. Reptiles are not quite so evident as in India and Australia, but crocodiles are numerous, and Russell's viper and other deadly Indian snakes are found here too; also the largest living snake, the king cobra or hamadryad, with a recorded length of $18 \mathrm{ft} .6 \mathrm{in}$. There are many lizards, turtles and tortoises, including the flying lizard. There are some three hundred fishes in the rivers, including catfish and carp.

The flora of Malaya has been written up by $\mathrm{H}$. N. Ridley, while from a horticultural point of view, the Western world has sent many collectors for its orchids. There are twenty-eight Vitis plants, sixteen Vacciniums and some seven hundred orchids and wild forms of many Western garden favourites like Canna orientalis. There are twenty-one Dracænes, thirteen Carex, five Scirpus, three Lemna and the tiny Waffia's microscopic flowers in the ditches and wells. Some plants familiar to British botanists include the common reed Phragmites communis on river banks, the chickweed, Stellaria media, as a weed of cultivation and the dandelion Taraxacum Dens-Leonis, an 'escape' on the Penang Hill. The Malayan flora totals some nine thousand species, and of more than three hundred trees in which the tall Dipterocarpaceæ predominate, some half are peculiar to the Peninsula. Lianas, rhododendrons, epiphytes and small palms are characteristic.

\section{Television in Colour and Stereoscopic Relief}

Hitherto, television has been confined to flat pictures. In a press demonstration on December 18, Mr. J. L. Baird demonstrated stereoscopic relief in combination with television in colour. Mr. Baird states that his first experiment in this direction was applied to his 600-line two-colour apparatus. The red image was made to 'view' the scene from a slightly different angle from the blue, so that the red and blue images constituted a stereoscopic pair, the receiving screen being viewed through glasses fitted with red and blue filters as in the anaglyph process. This, while simple, had the disadvantage that it was necessary to wear glasses and that, as the colour phenomenon was used to effect the change over from the right to the left eye, neither the colours nor the stereoscopy could ever be properly rendered. So far the object in mind had been to produce a system capable of being transmitted through the existing channels available to the B.B.C., but in an endeavour to produce as perfect a result as possible, it was decided to produce an entirely experimental apparatus regardless of existing practical limitations.

In the apparatus now demonstrated by Mr. Baird, the frame frequency has been increased from $50 / \mathrm{sec}$. to $150 / \mathrm{sec}$., the scanning altered to a field of 100 lines interlaced five times to give a 500-line picture, successive 100-line frames being coloured green, red and blue. At the transmitter a cathode ray tube is used in conjunction with photo-electric cells, the moving light spot being projected upon the scene transmitted. In front of the projecting lens a mirror device consisting of four mirrors at right angles splits the emerging light beam into two paths separated by a space equal to the separation of the human eye. By means of a revolving shutter the scene is scanned by each beam alternately, so that images corresponding to the right and left eye are transmitted in rapid sequence. Before passing through the shutter disk the light passes through a rotating disk with blue, red and green filters. Thus superimposed red, blue and green pictures blending to give a picture with full natural colours are transmitted for left and right eye alternately. At the receiver the coloured stereoscopic pairs of images are reproduced in sequence and projected upon a field lens, alternate halves of the projecting lens being exposed by means of a rotating shutter, the image of the shutter being projected upon the eye of the viewer so that his left and right eyes are presented alternately with the left and right images, the combined effect being a stereoscopic image in full natural colours.

\section{Poverty and Malnutrition in South Africa}

EvIDENOE given to the Industrial and Agricultural Requirements Commission by Dr. T. W. B. Osborn on March 17, 1941, has now been published under the title "Remedies for Poverty and Malnutrition in South Africa". (Pp. iii+22. Johannesburg : Central News Agency, Ltd., 1941. 2s. 6d.). Dr. Osborn, pointing out that the mines managements of the Rand have already convinced themselves that it pays to put their native labour force on a wellbalaneed ration, emphasizes the significance of the prevention of malnutrition in regard to infantile mortality and general physique among the Bantu. The potential production of foodstuffs in South Africa is considered more than sufficient to give each member of the community an ample balanced diet. Distribution is the major problem - getting the right food to the people, by increasing their purchasing power, subsidizing consumption, or free distribution. He criticizes milling practice in the cereal industry and asserts that it is essential that the germ of the wheat should go back into refined flour and mealie meal. The conversion of more skim milk into food for human consumption, development of the margarine industry on the grounds of price, in spite of the butter surplus, encouragement of soya bean growing, of the consumption of meat, fish and peanuts by the poorer sections of the community, and of the use of vegetables and fruit rich in vitamin C, such as guavas and red peppers, are also advocated.

The consumption of these foods so as to eliminate malnutrition should be encouraged within the present economic framework by a system of subsidies, preferably a combination of free distribution, subsidy to the consumer and subsidy to commerce. Dr. Osborn cites for example a scheme to encourage the use of mealie meal containing 5 per cent of soya bean meal, and then discusses the long-term solution of the problem of removing poverty in the midst of 
plenty. This means raising the general standard of living and making the economic struggle for existence less intense and ruthless. The final aims are to induce the maximum of economic efficiency, economic equity and personal freedom. Raising wages and reducing costs are not general remedies. They must be supported by measures to stimulate investment and consumption, and Dr. Osborn stresses the value of more generous State provision for sickness, old age and child welfare, the endowment of research, public works, consumer subsidies and the encouragement of drama and the arts. Means to check inflation are essential as well as the control of land values, the share market and overseas influences. Economic self-sufficiency he considers is not necessarily retrograde, but he emphasizes the necessity of unorthodox methods and also of safeguards against bureaucracy in the economic planning required.

\section{The Forests of India}

Ir would perhaps be difficult to find stronger evidence of the changes which have taken place in the management of the forests of India and the almost complete manner in which the Secretary of State for India, and the Central Government of India itself, are dissociating themselves from their administration, than is provided by the Inspector-General of Forest's Quinquennial Review ending March 31, 1939. (Ann. Return of Statistics relating to Forest Administration in British India for 1938-39 and Quinquennia] Review ending March 31, 1939. Govt. of India Press, Calcutta, 1941.) For well over half a century the forests of India, their protection and improve. ment (and incidentally the increasing revenue they yielded), had formed a personal pre-occupation of successive Secretaries of State for India and (with that spur) of successive Governors-General and Viceroys. With increasing efficiency in management it became no longer possible for an inspector-general to portray in an annual report, kept within official requirements of space, the work being carried out throughout India and Burma. The latter was therefore reduced to tabular statements of statistics only, whilst a quinquennial report gave an eye-picture of the progress in management and the position of the forest estate.

It can now be realized that these reports have the very highest value in the light of the new position brought about by the Government of India Act, 1935, under which the forests are transferred to the individual provinces. The India Forest Service at present numbers 219 officers, of whom 163 were recruited at home direct to the Service. Gradually, with the retirement of these officers, the forests and their management will become purely the affair of the various provincial Governments. Even the senior administrative appointments, conservators and chief conservators in provinces, will no longer, it is said, be made by the Central Government. The Government of India still maintains an InspectorGeneral of Forests, shorn of all power, who is at the same time president of the Forest Research Institute and College at Dehra Dun. At the College the officers for the new 'Superior Forest Services' of the individual provinces are to be trained. The Inspector-General is permitted to visit, on invitation, the various provinces, but his reports on such visits are purely advisory. In fact, as the Quinquennial Report for 1934-35 to 1938-39 indicates, the chief position in forestry administration of the IrispectorGeneral at the present time is his occupancy of the presidentship of the Research Institute. Out of 24 pages in this report less than six are devoted to describing work of purely forest management, and the remainder to forestry research work. Yet this latter is dealt with very fully in the annual reports of the Research Institute.

The annual revenue from the great forest estate of India and Burma for the year 1936-37 (before the separation of the latter) amounted to Rs.4,38,07,019, or well over three million pounds sterling. In addition nearly half a million pounds sterling of forest produce is given away free or at reduced rates. Many senior men with long experience in the administration of this great forest estate, the correct management and maintenance of which is vital to India as a whole, view with concern and distrust the devolution of their powers and responsibility by the Secretary of State and Governor-General.

\section{An Index to Horticultural Research}

THE availability of research results of a purely horticultural character has been greatly increased by the publication of Horticultural Abstracts by the Imperial Bureau of Horticulture and Plantation Crops, East Malling, Kent. Mr. D. Akenhead, deputy director of the Bureau, has now compiled an index to the first ten volumes, covering the period 1931-40 (Sept. 1941, 160 pp., 25s.). The volume contains a subject index and an alphabetical list of authors ; it is world-wide in scope, and demonstrates the prosecution of an enormous volume of horticultural research during the decade it reviews. Greatest use of the index demands its relation to the journal which it serves, but the research worker can see from the present volume whether any work in his particular line has been reported. Detail is quite adequate for modern needs, for a reference can be found to apple sauce as well as to Rhizopus arrhizus rot of that crop, and to the utilization of waste potatoes, in addition to rubidium absorption in potato disks. The subject index is compiled with the different crop plants as the chief points of interest. The volume certainly achieves its expressed object of making information as available to the Englishspeaking horticultural worker as possible.

\section{Health of Palestine}

According to the report for 1939 recently published by the Department of Health in Palestine, the country was so much disturbed by political strife in that year as to prevent development of health work. The health of the people, however, was remarkably good, and there were no important epidemics. The recorded incidence of infectious diseases was the lowest for many years, and the death-rate from them half that of 1931. The total population numbered 1,501,698, of which 60 per cent were Moslems, 30 